\title{
EVALUATION OF TRIBILOGICAL CHARACTERISTICS OF DUPLEX COATED 31CRMOV9 STEEL
}

\author{
VALOVA, M[arie] \& SCUHANEK, J[an]
}

\begin{abstract}
The paper resumes partial results of tribological testing of duplex coatings of tool steel. Steel samples (31CrMoV9) were nitrided and subsequently treated by PVD process. There were deposited different coatings (TiN, CrN, TiAlN and multilayer $3 x(C r N-T i N))$ with thickness 1 and $3 \mu \mathrm{m}$. Samples were tested and characteristics like nanohardness, hardness of duplex coating, friction coefficient (pin on disc), coating thickness (Calotest), resistance against adhesive wear (Scratch test) and abrasion size (HEF) were measured. Results of chemical composition, adhesion measured by Scratch test, friction coefficient measured by "HEF" tribometer and average weight wear are summarized in this paper
\end{abstract}

Key words: duplex coating, nanohardness, tribological properties, $P V D$

\section{INTRODUCTION}

The requirements for materials used in the machine parts production, especially their functional characteristics and service life are increasing at present. The need of strength, ductility and toughness on one hand and low weight, corrosion and wear resistance on the other hand, are often contradictory and with standard materials hardly realizable (Liscano et al., 2006).

Suitable solution of this formidable situation appears with a surface treatment, which can create the coating with special properties mentioned above. The example is a die, which keeps basic material characteristics and thanks to coating functional properties of its surface get improved. In this case there is a problem of cracking of the coating when overloaded. When wery hard and abrasion-resistant coating is applied on softer base material, the substrate deforms when loaded and the brittle coating cracks. That leads to intensive wear of coating and as a result of the die, too (Valova et al., 2009). The strengthening of substrate surface layers, e.g. by plasma nitriding, appears to be a suitable solution of the low strength of substrate. On the nitrided surface there is applied relevant PVD coating with required properties (Suchanek et al., 2009).

\section{EXPERIMENTAL}

The specimens from low-alloy steel 31CrMoV9 were austenitized, inert qas quenched and tempered. The duplex treatment proceeded in two phases. In the first phase the specimens were pulse plasma nitrided (further PN). In second phase different PVD coatings were deposited - a) TiN (thickness 1 and $3 \mu \mathrm{m}$ ), b) CrN (thickness 1 and $3 \mu \mathrm{m}$ ), c) TiAlN (thickness $3 \mu \mathrm{m}$ ) and d) multi*ajeen $3 \quad-\mathrm{CrN}$ ) (thickness $3 \mu \mathrm{m}$ ).

Chemical composition was measured by GDOES. The adhesion to the substrate was classified by a scratch test, where critical loads $L_{c}$ were evaluated. It was measured values of critical loads $L c$ according to specification prEN 1071-3. Nanohardness and elastic modulus of the coatings were measured by CSM method with maximum load $P_{\max }=670 \mathrm{mN}$.
The measurement methodics is described in (Lukes et al., 2010).

The specimens were tested on tribometer „HEF". The experiments were realized at the temperature $22^{\circ} \mathrm{C}$, with load 50 and $150 \mathrm{~N}$, all under conditions of dry friction. Other parameters: $\mathrm{v}=0,951 \mathrm{~m} / \mathrm{s}, \mathrm{L}=1000,2500,5000$ a $10000 \mathrm{~m}$, countepart - quenched steel 31CrMoV9.

\section{RESULTS AND DUSCUSSIONS}

Results of GDOES are shown in figure 1 and 2. Results of Scratch test are shown in table 1.

$\mathrm{X}$ axis, time, corresponds to depth profile of chemical composition. Yaxis signal, voltage, is only qualitative, no direct comparison of element can be done, because various coefficients are used for different elements.
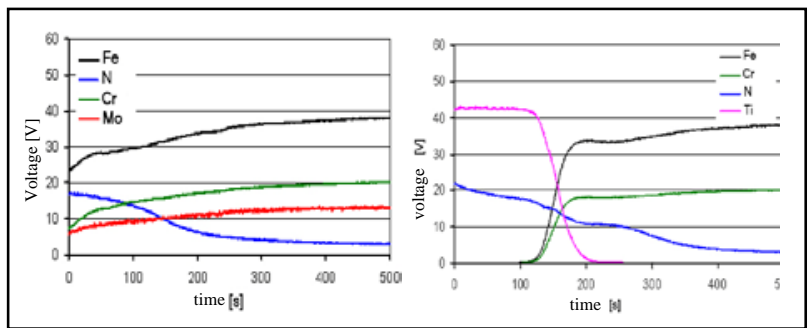

Fig. 1.Changes of chemical composition of plasma nitrided (left) and duplex treated - TiN (right) steel 31CrMoV9
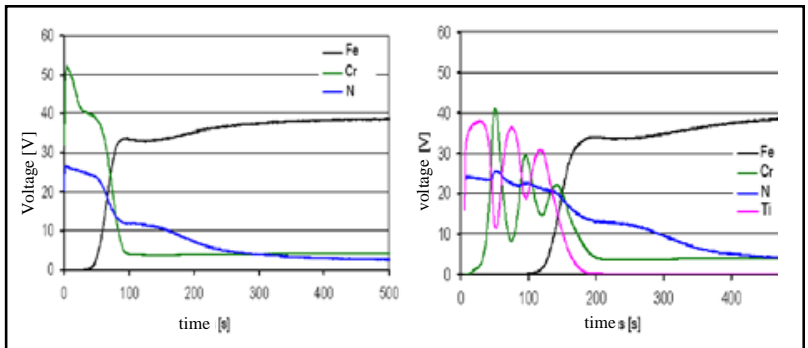

Fig. 2.Changes of chemical composition of duplex treated steel 31CrMoV9. CrN- left, 3x (TiN-CrN) - right

Depth profiles in graphs, valuated by GDOES, show steady transition of chemical composition from coating to base material. At multilayer 3x (TiN-CrN) are well visible changes of chemical composition in single layers of coating.

\begin{tabular}{|c|c|c|}
\hline Coating & $\mathrm{Lc}_{2}[\mathrm{~N}]$ & $\mathrm{Lc}_{3}[\mathrm{~N}]$ \\
\hline $\mathrm{TiN}$ & 78 & 87 \\
\hline $\mathrm{CrN}$ & 34 & 52 \\
\hline TiAlN & 52 & 61 \\
\hline $3 \times(\mathrm{TiN}-\mathrm{CrN})$ & 52 & 61 \\
\hline
\end{tabular}

Tab.1.Values of critical loads $\mathrm{Lc}_{2}$ and $\mathrm{Lc}_{3}$ measured with Scratch test 
As the results of Scratch test shows, tab. 1, the highest adhesion to the basic material was detected for the TiN coating and the lowest adhesion for the $\mathrm{CrN}$ coating. All the tested PVD coatings have sufficient values of critical load.

The results of nanohardness and elastic modulus are shown in table 2.

\begin{tabular}{|c|c|c|}
\hline Coating & Hardness [GPa] & E [GPa] \\
\hline TiN & $35,8 \pm 4,6$ & $504 \pm 80$ \\
\hline CrN & $26,9 \pm 3,4$ & $327 \pm 43$ \\
\hline TiAlN & $32,9 \pm 5,8$ & $497 \pm 98$ \\
\hline $3 x($ TiN-CrN) & $34,2 \pm 8,1$ & $566 \pm 83$ \\
\hline
\end{tabular}

Tab. 2. Modulus and hardness of coatings

Results of "HEF" tribometer are shown in table 2, 3 and figure 3, 4. Example of worn sample is at figure 5.

\begin{tabular}{|c|c|c|c|c|}
\hline Duplex coating & $1000 \mathrm{~m}$ & $2500 \mathrm{~m}$ & $5000 \mathrm{~m}$ & $10000 \mathrm{~m}$ \\
\hline TiN $(1 \mu \mathrm{m})$ & $+0,93$ & 0,37 & 3,47 & 10,24 \\
\hline TiN $(3 \mu \mathrm{m})$ & $+0,37$ & 0,13 & 1,17 & 2,20 \\
\hline CrN $(1 \mu \mathrm{m})$ & 1,63 & 4,10 & 12,76 & 25,56 \\
\hline CrN $(3 \mu \mathrm{m})$ & $+0,83$ & $+0,53$ & $+0,20$ & 1,46 \\
\hline TiAlN $(3 \mu \mathrm{m})$ & $+1,20$ & $+1,36$ & $+0,60$ & 1,00 \\
\hline $\begin{array}{c}\text { 3x(TiN-CrN) } \\
(3 \mu \mathrm{m})\end{array}$ & $+0,67$ & $+1,00$ & $+0,83$ & $+0,67$ \\
\hline
\end{tabular}

Tab. 3. Average weight wear $\left(10^{-6} \mathrm{~kg}\right)$ on slide way $(\mathbf{F}=\mathbf{5 0} \mathbf{~ N})$

\begin{tabular}{|c|c|c|c|c|}
\hline Duplex coating & $1000 \mathrm{~m}$ & $2500 \mathrm{~m}$ & $5000 \mathrm{~m}$ & $10000 \mathrm{~m}$ \\
\hline TiN $(1 \mu \mathrm{m})$ & 17,8 & 84,45 & 323,85 & 915,9 \\
\hline TiN $(3 \mu \mathrm{m})$ & 0,45 & 3,35 & 13,1 & 44,4 \\
\hline CrN $(1 \mu \mathrm{m})$ & 63,9 & 165,7 & 485,1 & 1118,3 \\
\hline CrN $(3 \mu \mathrm{m})$ & 29,6 & 111,15 & 216,1 & 416,8 \\
\hline TiAlN $(3 \mu \mathrm{m})$ & $+1,75$ & $+0,3$ & 4,1 & 23,9 \\
\hline $\begin{array}{c}3 x(T i N-C r N) \\
(3 \mu \mathrm{m})\end{array}$ & 8,1 & 20,33 & 39,2 & 103,27 \\
\hline
\end{tabular}

Tab.4. Average weight wear $\left(10^{-6} \mathrm{~kg}\right)$ on slide way $(\mathbf{F}=\mathbf{1 5 0} \mathbf{~ N})$

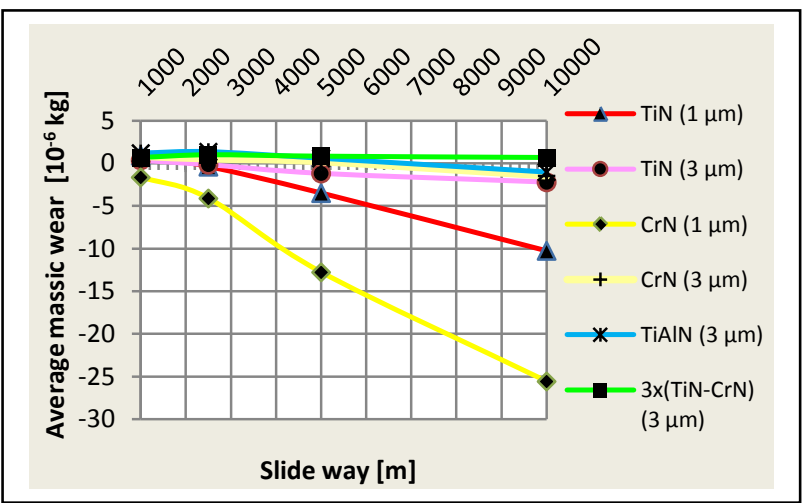

Fig. 3. Dependence of weight wear at slide way at load $50 \mathrm{~N}$

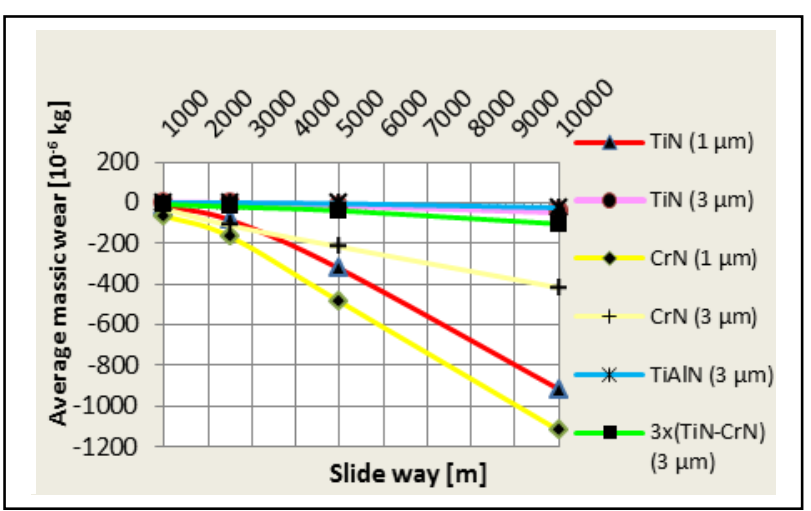

Fig. 4. Dependence of weight wear at slide way at load $150 \mathrm{~N}$

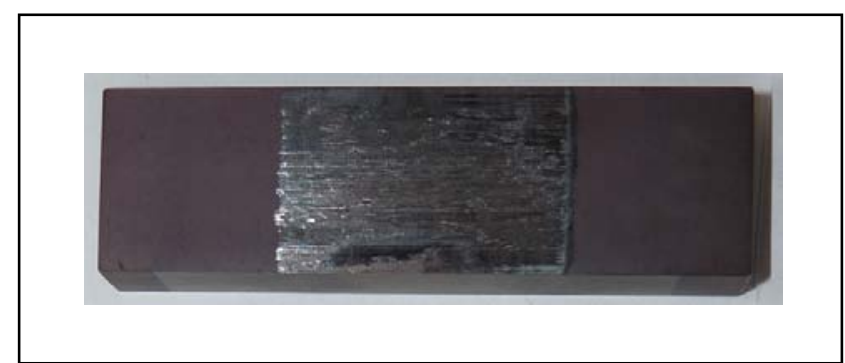

Fig. 5. Wear of sample with coating TiAlN after $10000 \mathrm{~m}$ at load $50 \mathrm{~N}$

From all tested coatings, the TiAlN has the best resistence against adhesive wear at both levels of load, lower $50 \mathrm{~N}$ and higher $150 \mathrm{~N}$. Under both load levels TiAlN has minimal and steady abrassive wear compared to other coatings. In case of 50 $\mathrm{N}$ load 3x(TiN-CrN) coating has even better results, because of adhesive diffusion from counterpart. Because of this, adhesion wear is minimal or even negative. For higher load TiAlN has smaller wear than $3 x(\mathrm{TiN}-\mathrm{CrN})$ coating. The coatings with thickness $1 \mu \mathrm{m}$ have markedly bigger wear than the same coatings with thickness $3 \mu \mathrm{m}$.

\section{CONCLUSION}

The conclusions drawn from the experiment show that duplex treatment is a useful way to increase the die service life.

In term of critical load, the most suitable is TiN coating with thickness $3 \mu \mathrm{m}$. This coating in combination with a nitrided substrate had low friction coefficient and small wear.

In term of wear, for both load, the best results are for TiAlN and multilayer $3 x(\mathrm{TiN}-\mathrm{CrN})$ coatings. For these 2 coatings, wear occurs in two phases. In $1^{\text {st }}$ phase due to adhesive wear of counerpart, the test sample coating thickness increase. This deposited materil mixes up together with the test sample coating. In the $2^{\text {nd }}$ phase, abrasive wear of resulting coating of the test sample starts. Abrasive wear of this layer is very low. Similar results gives coating TiN with thickness $3 \mu \mathrm{m}$.

Current thin abrasion-resistant surface layers and duplex coatings bring remarkable extension of service life and reliability to parts, tools and dies as confirmed by this research. Still most coating technologies have not managed to reach the limits of their possibilities so far.

This paper develops in more detail results listed in paper Characteristic of Duplex Coated Steel (Valova et al., 2010).

\section{ACKNOWLEDGEMENTS}

The research was financed by the Czech Ministry of Education, Youth and Sport within the frame of project SGS CVUT 2010 - OHK2-038/10.

\section{REFERENCES}

Liscano S., Gil L., Leon O., Cruz M., Staia M.: Cor. Surface \& Coating Techechnology 201, 4419 (2006)

Lukeš J., Šepitka J., Němeček J.: Dynamic Nanoindentation of Bovine Interver. end plate. In: Chemicke Listy 2010, vol. 104, no. S, p. 338-341. ISSN 0009-2770

Suchánek J., Jurči P., Zdravecká E.: Adhesive Wear of Duplex Treated Low Alloys Steels. Proceedings of the 2nd European Conference on Tribology. Pisa, Uni.Pisa, 2009, vol. 2, p. 791-796. ISBN 978-88-467-2426-7

Válová M., Suchánek J., Bláhová O.: Characterics of Duplex Coated Steels In: Chemicke Listy 2010, vol. 104/2010,no. 15, p. 378-381. ISSN 0009-2770

Válová M., Suchánek J., Bláhová O.: Vliv povlakování na zvyšování životnosti tvářecích nástrojů. In: Vrstvy $a$ povlaky 2009, DIGITAL GRAPHIC, Trenčín, s. 153 - 158 (2009) 